\title{
浴室の室内気候について
}

(浴室の計画に関する研究・II)

\section{正会員平山䕉*同斎藤平蔵**同 ○足羽洋保***}

この報告は、本年 1 月関東支部において発表した第 1 報1 に続く浴室の研究として、昨年末、熱海 $\mathrm{K}$ ホテルの 部屋付き浴室での室内気候実測結果である。

測定項目は、脱衣室と浴室の垂直温度分布、両室の比 較湿度、浴室の天井面、側壁面、休面の各温度、湯温、 外気温湿度、浴室之脱衣室の換気回数、浴室の照度之排 水騒音、人体表面からの蒸発水分量、等であって、今回 は、換気と防湿の立場から、主として温湿度関係を中心 に実測を行なっ た。

測定には熱電 対を用い、とれ を電子管式自記 記録計で昼夜に 亘り、連続的に 記録させたが、 てのうち、浴室

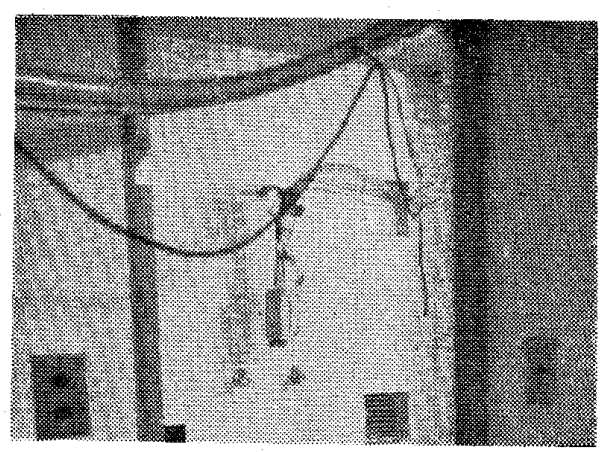

写 真
の湿度については、100\% を越える場合が多いので普通 のアスマン乾湿計では測定出来ない。

そこで、電動式アスマンのエレメント先端に金属製の 筒を取付け、中に小さなヒーターを入れて、筒内の空気 を温める事により内部の相対湿度を下げ、てれをビニー ル管をつないだ小型モーターで吸引して值を読取り、得 られた水蒸気圧から逆算して湿度を求めた (写真参照)。

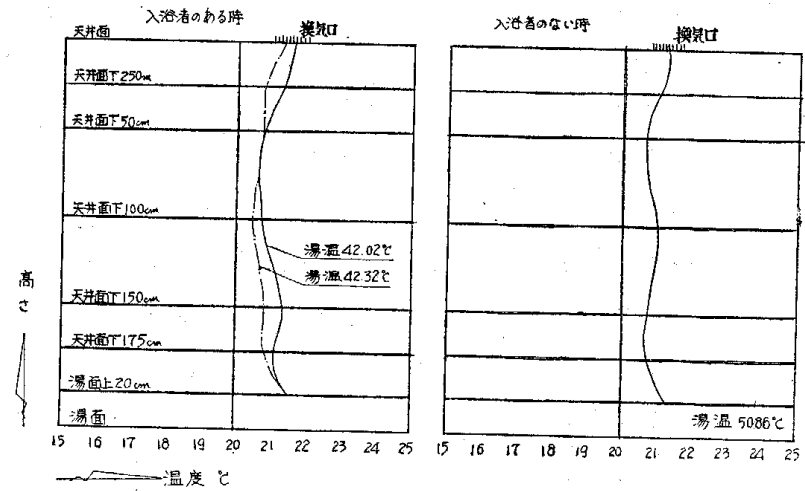

第 1 図 浴室垂苴温度分布

\section{測定結果について}

（1）浴室内の垂直温度分布は、第 1 図に示す通り、 湯表面の近くと天井面付近が最も高温で、中央辺りがま た高くなる独得の温度分布をしているが、ての種の外気 に面しない小さな浴室においては、垂直温度差は $1 \mathrm{deg}$

\footnotetext{
* 東京大学名誉教授 工博 ** 東京大学助教授 工博 *** 清水建設 $\mathrm{K} K$ 研究所（実測当時東京大学大学院）
}

を越えないものの様である。

また室内温度は、湯温自体よりも、むしろ入浴者の有 無や、外気温によって支配される事の方が大きいのでは ないかと思われるが、実測例に乏しいため、詳細は明ら かではない。

(2) 室内 気候について は、第2図の 様に、6つの 因子をグラフ 化してみる と、宝内温度 は湯温よりも 外気温のカ一 ブに近く、一

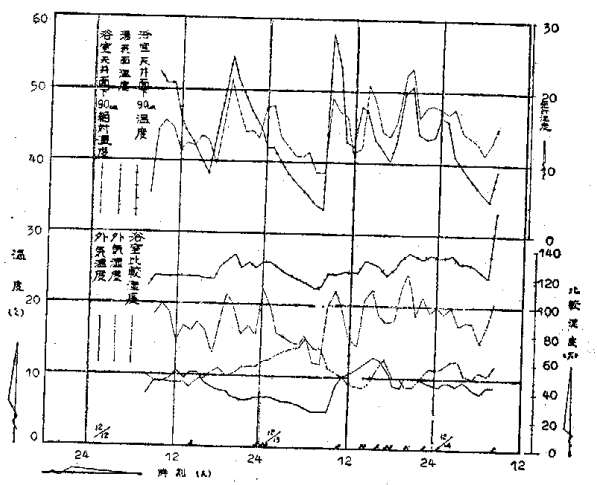

第 2 図 浴室内抢よび外気温湿度
方、湿度については、外気湿度には無関係で、湯温の高 い時か、湯温が低くても入浴者がある場合には、大抵 $100 \%$ を越えている事実に注目したい。

てれは、つまり、湯からの蒸発量を規制するものは、 湯温と、入浴者数が重要な园子である事を示している。

（3）前述の様に、入浴者があると、室内の水蒸気圧 が大分増加するが、この場合、増加の原因として、洗い 場における人体からの蒸発量と、浴槽から溢れて床面を 流れる湯からの蒸発量とが考觉られるが、その割合を見 る目安として、人体表面からの蒸発量を測定した。

これは、湯から上がって体表が乾くまでに要した時間 と、乾いたタオルで拭いて体表に付着した水分量を测る という、極めてラフな方法を用いたが、大体の見当はつ ける事が出事た。

その結果、成人男子では $70 \sim 140 \mathrm{mg} / \mathrm{sec}$, 成人女子で は $50 \sim 110 \mathrm{mg} / \mathrm{sec}$ 程度である。仮にてのままの状態が 続くものとすれば実測した浴室に 1 人入浴する之、全蒸 発量（=湯表面十床面人人体）の約 5 14\% を占める 值となるので、もし、2 3 人の入浴者があれば、かな り蒸発量が増す事になる。

（4）崖酸ガス法によって換気回数を求めた処、約 10 回/時の数值が出た。この值が果して無難なものであ るか否か害験值としては明らかではない。理論的な計算 式による適切換気量については次回に発表する予定。

〔註】1）温泉浴室の問題点（浴室の計画に関する研究 I ) 第 3 回関東支部研究発表会梗概集（1963 年 1 月） 